УДК 581.526

\author{
О. С. Климишин
}

Державний природознавчий музей НАН України

\title{
РІВНІ І СТУПЕНІ ОРГАНІЗАЦІЇ ФІТОСИСТЕМ
}

Із позицій системного підходу розглядаються універсальні принципи організації фітосистем, ïx ісрархічна підпорядкованість. Визначені біологічні кванти для основних рівнів організації фітосистем. Вводиться поняття “фітоциклоценон” (елементарна сукцесійна система) і обгрунтовується правомірність розгляду його як основної еволюційної одиниці фітоценосистемного рівня організації.

\author{
O. S. Klymyshyn
}

State Natural History Museum of NAS of Ukraine

\section{LEVELS AND STAGES OF ORGANIZATION OF PHYTOSYSTEMS}

From the position of systems approach the universal principles of phytosystems organization and their hierarchical subordination are examined. Biological quanta are determined for the basic levels of phytosystems organization. A concept "phytocyclocenon" (elementary seral system) is introduced. The legitimacy of its consideration as a basic evolutionary unit of phytocenosystem level of organization is grounded.

Особливою рисою розвитку фітоценології в останні десятиліття є застосування системного підходу $[1 ; 2 ; 6 ; 12 ; 13 ; 20 ; 32 ; 33]$. Перевага концепції системного підходу полягає в тому, що вона полегшує розуміння сутності предмета досліджень - певні явища стають аналогічними, порівняльними, поліпшується синтез, узагальнення та формулювання гіпотез. Окрім того, системний підхід дозволяє виявляти відсутність або неповноту інформації про об'єкт досліджень, в окремих випадках (інтерполяцією або екстраполяцією) передбачати властивості відсутніх частин описів, а найголовніше - визначати напрями та завдання наукових досліджень.

Універсальні принципи організації, моделі та форми, шляхи та напрямки трансформації різних типів систем різних рівнів і ступенів організації стали предметом дослідження окремої науки - тектології [43], яка вивчає найзагальніші структурні типи систем різних класів і найзагальніші закони їх перетворень, універсальні закономірності трансформаційних процесів. Системний підхід у фітоценології передбачає вивчення структури, організації та динаміки фітосистем різного рівня інтеграції, встановлення взаємозв'язків і взаємозалежностей між ними. Рослинний організм, фітоценопопуляція, фітоценоз, сукцесійна система, рослинний покрив є типовими біологічними системами і типовими об'єктами системного аналізу.

Нові завдання 3 поглибленого вивчення фітоценосистем і прогнозування змін рослинного покриву змусили дослідників посилено розробляти теоретичні засади фітоценології як одного 3 найважливіших розділів екології, що вивчає автотрофну ланку біосфери. Це знайшло відображення у низці публікацій [4; 6; 11-17; 29; 36-38; 40; 47]. Серед цих завдань постають і питання самоорганізації живої матерії як на рівні органі-

(C) О. С. Климишин, 2008 
зму, так і на рівні угруповання, які до цього часу залишаються достатньо дискусійними $[5 ; 14 ; 17 ; 39 ; 41 ; 42 ; 45]$.

Індивідуальний розвиток організмів, що належать до різних біологічних видів, відзначається варіабельністю, хоч і підпорядковується загальній схемі. Еволюція надорганізмених систем (філоценогенез), утворених автотрофними організмами, також характеризується різними специфікаціями, залежно від первинного набору видів. Для зазначених процесів спільними є особливості самоорганізації, під якою розуміють жорстку послідовність фізико-хімічних та біологічних явищ у природних системах, зумовлених як зовнішніми, так і внутрішніми чинниками, що призводять до виникнення структурно-функціональної єдності.

Безперервний потік індивідуумів, особин або біологічних індивідуальностей, які проходять свій життєвий цикл, Г. П. Короткова [23] розглядає як біологічні кванти, просторово-часові дискретності. Невід’ємними загальними властивостями їх, які обумовлюють можливість їх існування та філогенію, $є$ стійкість у часі та здатність до самовідтворення [3; 18]. Поняття біологічний квант, онтогенез, життєвий цикл може бути застосоване до будь-якого рівня організації фітосистем, у тому числі й до надорганізменого, хоч щодо числа цих рівнів та їх розмірностей не існує єдиної думки.

На наш погляд, для виділення основних рівнів організації фітосистем можна застосувати ті ж критерії, які є визначальними і найголовнішими для виділення основних рівнів організації живого загалом [7; 8; 10]. Для фітосистем - це ступінь цілісності, універсальність, самостійність існування, основна функція в рослинному світі і наявність механізмів саморегуляції. Відповідно до такого підходу нами прийнята за основу схема, яка є близькою до запропонованих Є. М. Лавренком [26; 27], К. М. Завадським [19], М. А. Голубцем [8; 10] і Я. П. Дідухом [11]. Останній виділяє чотири рівні організації фітосистем - організмений, популяційно-видовий, фітоценотичний та фітоценохоричний. Пізніше Я. П. Дідухом [12] до цих рівнів був долучений ще й п'ятий фітосферний, а фітоценохоричний рівень переведений ним у ранг регіонального.

Нами виділяються три основні рівні організації фітосистем - організмений, популяційний та фітоценосистемний (табл.). Для того щоб мати змогу розрізняти чи відмежовувати основні рівні організації фітосистем від різноманітних вторинних, неуніверсальних і несамостійних рівнів їх структуризації, можна використати термін М. А. Голубця [8] “ступені структуризації” або К. М. Завадського [18] “ступені організації.” У нашій статті використовується останній термін. Виходячи з цього, всередині систем основних рівнів організації фітосистем за ознаками їх структурної цілісності та функціональної специфіки нами виділяються ступені організації фітосистем.

Уся різноманітність рослин на планеті належить до одного основного, універсального, відносно самостійного, стійкого й первинного рівня організації - організменого. Поділ його за ознаками внутрішньоорганізмених структур або за ознаками складності (одноклітинні, багатоклітинні) є другорядним і підпорядкованим. Самостійно існує лише одноклітинний організм. Рослинний організм (індивід) являє собою систему й у той же час сукупності цих елементарних фітосистем на вищих рівнях інтеграції формують інші фітосистеми (клони (кондивіди), популяції), або є складовими елементами фітоценосистем (синузій, фітоценозів тощо). Біологічним квантом цього рівня є особина.

Надорганізмені фітосистеми мають суттєві відмінності від організмених, головною з яких є відсутність спадковості і, до певної міри, дискретності, яка властива передусім поодиноким предметам дійсності. Проте це не позбавляє надорганізмені системи 
індивідуальності та реальності, а свідчить лише про існування іншого, а саме надорганізменого типу дискретності, звичайно з різним рівнем цілісності.

Другим з основних рівнів організації фітосистем $є$ популяційний. Популяційний підхід відіграє визначальну роль у теорії фітоценології, згідно з яким відкидається організмістське розуміння фітоценозу, а останній трактується як континуальна система ценопопуляцій [30]. Популяція визнається основною одиницею мікроеволюції [11; 40] і характеризується не лише певною будовою, а й здатністю до саморегуляції чисельності і вікового складу, фенотипічною і генотипічною структурою, рівнем стабільності та еволюційної пластичності.

Основні категоріальні одиниці функціонування фітосистем

Таблицчя

\begin{tabular}{|c|c|c|c|c|}
\hline $\begin{array}{c}\text { Основні рівні } \\
\text { організації }\end{array}$ & $\begin{array}{c}\text { Ступені } \\
\text { організації }\end{array}$ & $\begin{array}{c}\text { Елементи } \\
\text { системи }\end{array}$ & $\begin{array}{c}\text { Форми } \\
\text { розвитку }\end{array}$ & $\begin{array}{c}\text { Біологічні } \\
\text { кванти } \\
\end{array}$ \\
\hline Організмений & Клоновий & Особина & $\begin{array}{c}\text { Онтогенез } \\
\text { Синонтогенез }\end{array}$ & Особина \\
\hline Популяційний & Ценопопуляційний & $\begin{array}{l}\text { Особина } \\
\text { Кондивід } \\
\end{array}$ & $\begin{array}{c}\text { Популяційна } \\
\text { хвиля }\end{array}$ & Популяція \\
\hline \multirow[t]{5}{*}{ Фітоценосистемний } & & & $\begin{array}{c}\text { Філоценогенез } \\
\text { (трансгенез і флорогенез) }\end{array}$ & \multirow[t]{5}{*}{$\begin{array}{l}\text { Фітоцикло- } \\
\text { ценон }\end{array}$} \\
\hline & Фітоценотичний & $\begin{array}{c}\text { Ценопопуляція } \\
\text { Синузія } \\
\end{array}$ & Первинна сукцесія & \\
\hline & $\begin{array}{l}\text { Фітоцикло- } \\
\text { ценотичний }\end{array}$ & Фітоценоз & Онтоценогенез & \\
\hline & Фітоценохоричний & Фітоциклоценон & & \\
\hline & Фітосферний & Фітоценохоріон & & \\
\hline
\end{tabular}

Сукупність особин виду, що зростає в межах одного угруповання, В. В. Петровський [35] і А. А. Корчагін [24] запропонували називати "ценозною популяцією", або "ценопопуляцією". При такому визначенні зберігається уявлення про "популяцію" як набір біотипів виду, що властивий певному типу умов існування і який займає територію, відокремлену від територій, зайнятих іншими популяціями цього ж виду. До найголовніших властивостей ценопопуляцій Ю. А. Злобін [22] відносить: складність, яка полягає в характері набору елементів (особин) у ценопопуляції та особливостях взаємодії між ними з урахуванням щільності мережі зв'язків елементів; різноманітність, що визначається якісною неоднорідністю елементів у межах ценопопуляції; цілісність, яка забезпечує внутрішню організованість і взаємозалежність елементів із розподілом ії на структурну та функціональну цілісність; стійкість, що виявляється у збереженні ценопопуляції за дії несприятливих чинників.

Усі найістотніші первинні процеси еволюційних перетворень, які відбуваються в популяції, визначаються ії взаємодією 3 природним середовищем. Фітопопуляція $\epsilon$ універсальною, цілісною, територіальною, часовою, динамічною та самостійною структурно-функціональною системою. Вона має всі без винятку біотичні властивості виду. Вид же, як правило, $є$ сукупністю окремих популяцій і як функціональна система існувати не може. Тому, поділяючи позицію М. А. Голубця [7; 9], використання терміна "вид" для означення основного рівня організації вважаємо неправомірним. Популяційний рівень організації фітосистем вважають основним і інші дослідники $[21 ; 22$; $25 ; 31]$. Біологічним квантом цього рівня є власне популяція.

Третім основним, універсальним рівнем організації фітосистем, який нами виділяється, є фітоценосистемний, що включає фітоценосистеми різного ступеня організації - від синузії до фітосфери (див. табл.). Фітоценосистема (у широкому значенні) 
визначається як сукупність рослинних організмів, які формують специфічне фітосередовище, що дозволяє зростання певного набору видів у певному кількісному співвідношенні і каузально взаємодіє із середовищем у певних конкретних умовах [28].

Фітоценосистеми відрізняються від фітосистем нижчого рангу слабкою інтегрованістю або низьким рівнем системності, більшою автономністю елементів, здатністю їх заміщення, більшою диференційованістю (що знаходить своє відображення у синтаксономічному різноманітті) та різномасштабністю. До найголовніших властивостей фітоценосистем належать різноманітність, складність, відмінність, стійкість, емерджентність і неідентичність [29].

Структура фітоценосистем формується у процесі еволюції в якомусь ланцюгу змінних середовищ і відображає просторово-часові чинники дій цих середовищ. Головними типами структур фітоценосистем є статичні (територіальна, еколого-ценотична, ценопопуляційна та флористична) та динамічні (сукцесійна та еволюційна) [12].

Фітоценосистеми та їх підсистеми (елементи) відзначаються значною кількістю властивостей, ознак, які змінюються у просторово-часових параметрах. Застосування системного підходу у дослідженні закономірностей зміни цих властивостей і ознак необхідне для виявлення характеру основних взаємозв'язків і кількісних взаємовідносин між елементами системи, а також їх зв'язків із зовнішнім середовищем [1; 44; 48; 49].

Теоретично на фітоценосистемному рівні можна виділити значну множину ступенів організації, проте зазвичай виділяються найголовніші, які визначають основні аспекти організованості, функціонування та розвитку фітоценосистем.

Перший ступінь фітоценосистемного рівня організації фітосистем фітоценотичний, елементом якого є ценопопуляція. За Б. М. Міркіним [30], поняття “фітоценоз” можна прийняти, розуміючи під ним лише ділянку, умовно виділену з фітоценотичного континууму, або сукупність популяцій рослин (ценопопуляцій), пов'язаних умовами зростання та взаємовідносинами у фітоценозі у межах більшменш одноманітного комплексу чинників середовища. Таке визначення (автор називає його прагматичним) є доволі гнучким, не прив'язаним до домінантів і едифікаторів, які здебільшого мають широку екологічну амплітуду, внаслідок чого встановлення за ними фітоценозу втрачає чіткість.

Фітоценотичний ступінь організації фітоценосистем немає підстав трактувати одним з основних рівнів організації фітосистем, зважаючи на континуальність рослинного покриву і ту обставину, що фітоценози є лише однією зі стадій сукцесійних змін. Фітоценози не можна вважати і біологічними квантами фітоценосистемного рівня організації, оскільки у переважній більшості випадків вони не відтворюють самих себе.

Наступний ступінь організації фітоценосистем ми визначаємо як фітоциклоценотичний. Він представлений сукцесійними циклами, або “фітоциклоценонами”. Можливо, як синонім сукцесійного циклу, тут краще підійшов би термін “фітоценоцикл”, проте він уже зайнятий П. М. Овчинниковим [34]. Пізніше цей термін також використовували Ю. Р. Шеляг-Сосонко і Я. П. Дідух [46] під час досліджень структури флори Гірського Криму для відображення різної широти локальної екологоценотичної амплітуди видів.

Фітоциклоценон визначається нами як комплекс (елементарна сукцесійна система) корінного та похідних від нього серійних фітоценозів, що змінюють один одного у часі в межах певної ділянки території (виділу) корінної асоціації в процесі алогенноавтогенної (дигресивно-демутаційної) сукцесійної трансформації, розвиток якого починається та завершується фітоценосистемою клімаксового типу - субклімаксовою, 
клімаксовою або постклімаксовою (якщо розуміти під клімаксовою таку фітоценосистему, яка ще не відмирає).

Сукцесійна система, за визначенням С. М. Разумовського [37], може трактуватись як мінімальна біоценотична одиниця, що може самовідтворюватися. На нашу думку, саме фітоциклоценон, як елементарна сукцесійна система, і $є$ тим біологічним квантом, який здатен до самовідновлення і який можна вважати основною еволюційною одиницею фітоценосистемного рівня організації.

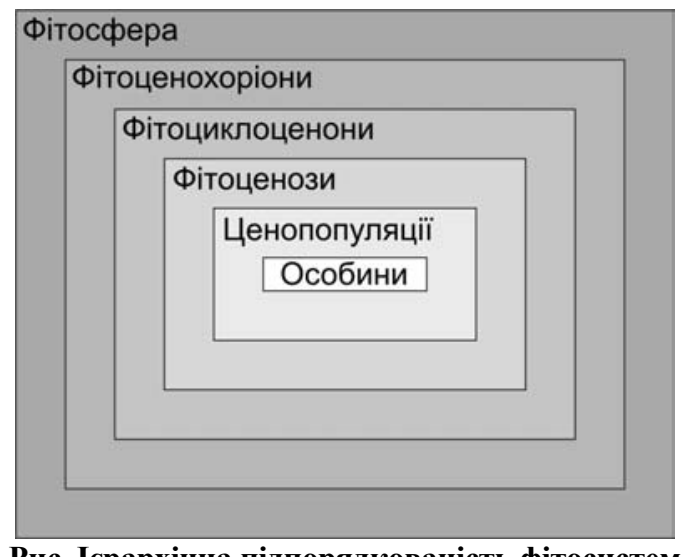

Рис. Ієрархічна підпорядкованість фітосистем

Фітоценохоричний ступінь фітоценосистемного рівня організації представлений фітоценохоріонами або макрофітоценосистемами, які визначаються нами як макросукцесійні системи, що складаються з комплексів фітоциклоценонів корінних асоціацій і серійних фітоценосистем первинних сукцесій у межах певного регіону: району, округу, провінції тощо. Близьким до такого розуміння фітоценохоріону є визначення С. М. Разумовського [37; 39], за яким угруповання, що співіснують у регіональному масштабі, організовані у сукцесійну систему. Проте у цьому визначенні відсутнє посилання на елементи такої системи.

Фітосферний ступінь організації представляє рослинний покрив земної кулі (або фітострома), який можна розглядати як мегафітоценосистему планетарного масштабу.

\section{Висновок}

Застосовуючи системний підхід, ієрархію фітосистем можна розглядати наступним чином. Фітоценосистемою планетарного рангу є фітосфера (рис.), що складається із сукупності фітоценохоріонів - макрофітоценосистем (макросукцесійних систем) регіонального рівня, елементами яких $€$ сукцесійні комплекси клімаксових або субклімаксових асоціацій. Останні, у свою чергу, складаються із сукупностей фітоциклоценонів (елементарних сукцесійних систем ділянок корінних асоціацій). Елементами фітоциклоценонів $є$ фітоценози. Фітоценози, як фітоценосистеми, складаються 3 фітосистем (елементів) нижчого рівня інтеграції - ценопопуляцій і окремих індивідуумів (особин).

\section{Бібліографічні посилання}

1. Александрова В. Д. Растительное сообщество в свете некоторых идей кибернетики // Бюлл. Моск. о-ва испытат. природы. Отд. биологии. - 1961. - Т. 66, вып. 3. - С. 101-113.

2. Александрова В. Д. О методе моделирования в фитоценологии // Бот. журн. - 1970. Т. 55, № 3. - С. 369-375. 
3. Беклемишев В. Н. Пространственная и функциональная структура популяций // Бюлл. Моск. о-ва испытат. природы. Сер. биол. - 1960. - Т. 65, вып. 2. - С. 41-50.

4. Быков Б. А. Биоценозы и эволюция // Флора и растительные ресурсы Казахстана. - Алма-Ата: Наука КазССР, 1975. - С. 23-35.

5. Василевич В. И. Надорганизменные системные уровни и некоторые черты их структуры / В. И. Василевич, В. С. Ипатов // Структурные уровни биосистем. - М.: Наука, 1967. C. $158-172$.

6. Василевич В. И. Очерк теоретической фитоценологии. - Л.: Наука, 1983. - 247 с.

7. Голубець М. А. Три основні рівні організації живого на планеті // Вісник АН УРСР. 1977. - № 3. - С. 76-86.

8. Голубец М. А. Актуальные вопросы экологии. - К.: Наук. думка, 1982. - 157 с.

9. Голубец М. А. Биотическая эволюция: сущность, условия, факторы, особенности // Методологические проблемы эволюционной теории. - Тарту: Изд-во Ин-та зоологии и ботаники АН ЭССР, 1984. - С. 50-52.

10. Голубець М. А. Біотична різноманітність і наукові підходи до ії̈ збереження. - Львів: Ліга-Прес, 2003. - 33 с.

11. Дідух Я. П. Еволюція фітоценосистем і роль антропогенного фактора в її процесах // Укр. ботан. журн. - 1987. - Т. 44, № 2. - С. 86-93.

12. Дидух Я. П. Растительный покров Горного Крыма (структура, динамика, эволюция, охрана). - К.: Наукова думка, 1992. - 256 с.

13. Дидух Я. П. Популяційна екологія. - К.: Фітосоціоцентр, 1998. - 192 с.

14. Дідух Я. П. Теоретичні проблеми еволюції рослинного покриву // Ю. Д. Клеопов та сучасна ботанічна наука: Матеріали читань, присвячених 100-річчю $з$ дня народження Ю. Д. Клокова. - К.: Фітосоціоцентр, 2002. - С. 12-26.

15. Емельянов И. Г. Разнообразие и его роль в функциональной устойчивости и эволюции экосистем. - К., 1999. - 168 с.

16. Жерихин В. В. Природа и история травяных биомов // Степи Евразии: проблемы сохранения и восстановления. - С-Пб-М.: Институт географии РАН, 1993. - С. 29-49.

17. Жерихин В. В. Усечение сукцессий: возможный механизм диверсификации биомов // Избранные труды по палеобиологии и филоценогенетике. - М.: КМК, 2003. - С. 173-188.

18. Завадский К. М. Основные формы организации живого // Философские проблемы современной биологии. - М., Л., 1966. - С. 29-47.

19. Завадский К. М. Вид и видообразование. - Л.: Наука, 1968. - 404 с.

20. Злобин Ю. А. Исследование механизмов, определяющих межвидовые ассоциированности и фитоценотическую структуру растительного покрова // Бот. журн. - 1976. - Т. 61, № 4. - С. 466-479.

21. Злобин Ю. А. Ценопопуляционный уровень в решении проблем фитоценологии / Ю. А. Злобин, В. М. Кохановский, И. Б. Сухой // Флора и растительность Украины. - К.: Наукова думка, 1986. - С. 41-43.

22. Злобин Ю. А. Принципы и методы изучения ценотических популяций растений. - Казань: Изд-во Казан. ун-та, 1989. - 146 с.

23. Короткова Г. П. Происхождение и эволюция онтогенеза. - Л.: Изд-во ЛГУ, 1979. - 294 с.

24. Корчагин А. А. Внутривидовой (популяционный) состав растительных сообществ и методы его изучения // Полевая геоботаника. - М.-Л.: Наука, 1964. - Т. 3. - С. 63-131.

25. Куркин К. А. Ценопопуляции как системы особей и как элементы фитоценозов: системно-иерархический подход / К. А. Куркин, А. Р. Матвеев // Бюлл. Моск. о-ва ипытат. природы. Отд. биол. - 1981. - Т. 86, вып. 4. - С. 54-74.

26. Лавренко Е. М. Основные закономерности растительных сообществ и пути их изучения // Полевая геоботаника. - М.-Л.: АН СССР, 1959. - Т. 1. - С. 23-75.

27. Лавренко Е. М. Об уровнях изучения органического мира в связи с познанием растительного покрова // Изв. АН СССР. Сер. биол. - 1964. - № 1. - С. 32-46.

28. Малиновський А. К. Системний підхід у фітоценології // Наук. зап. Держ. природозн. музею. - Львів, 2007. - Вип. 23. - С. 119-136. 
29. Миркин Б. М. Фитоценология. Принципы и методы / Б. М. Миркин, Г. С. Розенберг. М.: Наука, 1978. - 212 с.

30. Миркин Б. М. Теоретические основы современной фитоценологии. - М.: Наука, 1985. - 136 с.

31. Миркин Б. М. Заметки о «Перспективах теории фитоценологии» // Биологические науки. - 1989. - № 11. - С. 65-76.

32. Ниценко А. А. Структура растительного покрова и ее изучение // Тр. Петергоф. биол. инта. - 1973. - T. 22. - C. 275-285.

33. Норин Б. Н. Растительный покров: ценотическая организация и объекты классификации // Бот. журн. - 1983. - Т. 68, № 11. - С. 1449-1455.

34. Овчинников П. Н. К истории растительности юга Средней Азии // Совр. ботаника. 1940. - № 3. - С. 23-48.

35. Петровский В. В. Синузии как формы совместного существования растений // Бот. журн. - 1961. - Т. 46, № 11. - С. 1613-1626.

36. Работнов Т. А. Фитоценология. - 2-е изд. - М.: Изд-во МГУ, 1983. - 296 с.

37. Разумовский С. М. Основные закономерности сукцессионной динамики фитоценозов // Моделирование биогеоценотических процессов. - М.: Наука, 1981. - С. 47-62.

38. Разумовский С. М. Закономерности динамики биогеоценозов. - М.: Наука, 1981. - 232 с.

39. Разумовский С. М. Избранные труды. - М.: КМК Press, 1999. - 560 с.

40. Северцов А. С. Основы теории эволюции. - М.: Изд-во МГУ, 1987. - 320 с.

41. Ситник К. М. До питання про еволюцію екосистем / К. М. Ситник, М. А. Голубець // Укр. ботан. журн. - 1983. - Т. 40, № 1. - С. 1-9.

42. Тахтаджян А. Л. Макроэволюционные процессы в истории растительного мира // Бот. журн. - 1983. - Т. 68, № 12. - С. 1593-1603.

43. Тахтаджян А. Л. Принципы организации и трансформации сложных систем: эволюционный подход. - С.-Пб., 1998. - 230 с.

44. Фрей Т. Э.-А. Фитоценоз как многомерная стохастическая система // Тр. Моск. о-ва испытат. природы. Отд. биол. - 1970. - Т. 38. - С. 237-247.

45. Хайтун С. Д. Фундаментальная сущность эволюции // Вопр. философии. - 2001. - № 2. C. 152-166.

46. Шеляг-Сосонко Ю. Р. Ялтинский горно-лесной государственный заповедник. Ботаникогеографический очерк / Ю. Р. Шеляг-Сосонко, Я. П. Дидух. - К.: Наукова думка, 1980. - 184 с.

47. Шеляг-Сосонко Ю. Р. Методология геоботаники / Ю. Р. Шеляг-Сосонко, В. С. Крисаченко, Я. И. Мовчан. - К.: Наукова думка, 1991. - 272 с.

48. Шмальгаузен И. И. Интеграция биологических систем и их саморегуляция // Бюлл. Моск. о-ва ипытат. природы. Отд. биол. - 1961. - Т. 66, вып. 2. - С. 104-134.

49. Шмальгаузен И. И. Кибернетические вопросы биологии. - Новосибирск: Наука, 1968. - 223 с.

Надійшла до редколегії 10.04.2007 